\title{
Response of Nitrogen and Azospirillum Inoculation on Growth and Yield of Onion (Allium cepa L.) cv. Pusa Red
}

\author{
Anish Kumar ${ }^{1}$, Balaji Vikram ${ }^{2 *}$ and P.K. Singh ${ }^{1}$ \\ ${ }^{1}$ Department of Horticulture, Post Graduate College, Ghazipur -233001 (U.P.) India \\ ${ }^{2}$ Department of Horticulture, Sam Higginbottom University of Agriculture, Technology and \\ Sciences, Allahabad-211007 (U.P.) India
}

*Corresponding author

\section{A B S T R A C T}

\section{Keywords \\ Onion, Nitrogen, \\ Azospirillum, \\ Growth and yield \\ Article Info \\ Accepted: \\ 12 May 2019 \\ Available Online: \\ 10 June 2019}

\begin{abstract}
The present investigation was carried out at main horticulture research farm of Post Graduate College Ghazipur, U.P. during the winter season of year 2015-16. The application of nitrogen along with Azospirillum increased the growth and yield of onion. Two biofertilizer treatments $\left(\mathrm{B}_{0}=\right.$ control and $\mathrm{B}_{1}=$ Azospirillum) was treated at four different levels of nitrogen $\left(\mathrm{N}_{0}=\right.$ no nitrogen, $\mathrm{N}_{1}=80 \mathrm{~kg} \mathrm{ha}^{-1}, \mathrm{~N}_{2}=100 \mathrm{~kg} \mathrm{ha}^{-1}, \mathrm{~N}_{3}=120 \mathrm{~kg}$ $\mathrm{ha}^{-1}$ ) on onion $\mathrm{cv}$. Pusa Red. The experiment was conducted in randomized block design with 3 replications. The maximum plant height $49.10 \mathrm{~cm}$, leaf length $44.93 \mathrm{~cm}$, number of leaves per plant 9.32 , diameter of bulb $4.75 \mathrm{~cm}$, weight of bulb $38.10 \mathrm{~g}$, bulb yield $(8.37 \mathrm{q}$ $\left.\mathrm{ha}^{-1}\right)$ was found by applying $120 \mathrm{~kg} \mathrm{ha}^{-1}$ along with $\left(\mathrm{B}_{1} \mathrm{~N}_{3}\right)$ Azospirillum. However, the maximum yield was recorded $\left(279.22 \mathrm{q} \mathrm{h}^{-1}\right)$ with rest doses of nitrogen and Azospirillum.
\end{abstract}

\section{Introduction}

Onion (Allium cepa L.) is an important underground vegetable bulb crop of tropical and subtropical part of the world. Onion is considered to be the second most important vegetable crop grown in the world after tomatoes. It is an indispensible item in every kitchen used as vegetable and condiment used to flavor many of the food stuffs. Therefore, onion is popularly referred to the 'Queen of the kitchen'. In addition, onion is used as salad and pickle. Recently, onion is being employed by processing industry to a greater extent for preparing dehydrated onion forms like powder and flakes. In the world, India stands first in area and ranks second in production after China; the total area in India under onion production during 2018-19 was 23.62 million tonne. Maharashtra, Uttar Pradesh, Orissa, Karnataka and Rajasthan are the major onion producing states in India. Presently the major export markets for Indian onions are Middle East and Gulf countries, Singapore, Malaysia, Sri Lanka, Bangladesh, and Japan. Onion gives higher yield per unit area. India is gifted with a wide range of agroclimatic conditions, which enables the production of vegetables throughout the year in one part of the country or the other and also 
maintaining continuous supply of fresh vegetables. In Karnataka, onion is produced throughout the year. During kharif - 2006-07 the area cultivated with onion was 1.31 lakh ha with the production of 7.56 lakh tonne (Joshi, 2005) which illustrates the poor productivity and the shelf life of onions produced during kharif has been found to be poor. Several factors viz., lack of suitable variety (ies), poor nutrient management practices and improper storage techniques, have been identified as major cause for poor productivity, quality and storability of kharif onion. Onion being semi perishable crop gets deteriorated during storage, transportation and marketing. Due to excessive use of chemical (especially nitrogenous) fertilizers onion gets spoiled very soon in storage (NHRDF, 2012). In this regard, it becomes essential to study the influence of different (both organic and inorganic) sources of nitrogen on productivity and storability of the onion during kharif season. Onion (Allium cepa L.) is an important member of the genus Allium of family Amaryllidaceae. Onion and Garlic are most important bulb crops grown in India. Bio-fertilizers are the culture of bacteria which benefit the plants by providing nitrogen used mostly to release plant nutrients available from rhizosphere and stimulate plant growth and is therefore known as biologicalnitrogen fixation (Singh and Pandey, 2006). It is fixed in soil by chemically fixed nitrogen and biologically fixed nitrogen both.

\section{Materials and Methods}

The experiment was conducted in the Vegetable Research Farm, Department of Horticulture, Post Graduate College, Ghazipur during the Rabi season of 2015-16. The experimental field is situated in Gora Bazar area of Ghazipur city. All the facilities necessary for conducting the experiment, including labour and resources, which are necessary for normal cultivation were readily available. The present investigation entitled "Response of Nitrogen and Azospirillum inoculation on growth and yield of onion (Allium cepa L.)" was conducted during the winter (Rabi) season of 2015-16 at vegetable research form, Department of Horticulture, P.G. College, Ghazipur (U.P.). Two biofertilizer treatments $\left(\mathrm{B}_{0}=\right.$ control and $\mathrm{B}_{1}=$ Azospirillum) was treated at four different levels of nitrogen $\left(\mathrm{N}_{0}=\right.$ no nitrogen, $\mathrm{N}_{1}=80 \mathrm{~kg}$ $\mathrm{ha}^{-1}, \mathrm{~N}_{1}=100 \mathrm{~kg} \mathrm{ha}^{-1}, \mathrm{~N}_{1}=120 \mathrm{~kg} \mathrm{ha}^{-1}$ ) on onion cv. Pusa Red. The experiment was laid out in Randomized Block Design with 8 treatments. The treatments were replicated three times. A normal size of nursery bed $(3.0 \mathrm{~m} \times 1.0 \mathrm{~m})$ was prepared in the departmental nursery in the month of December 2015. The soil of nursery bed was prepared thoroughly and than a mixture consisting of five parts of clean garden soil, two parts of FYM and one part of clean sand was used as a $2-3 \mathrm{~cm}$ thick bedding before the seeds were sown in lines at $5 \mathrm{~cm}$ apart in the bed. Then the seeds were covered with a thin layer of above mixture and water was sprinkled. Thereafter, whenever water was required, irrigation was provided in the nursery bed. The experimental field was prepared by ploughing with a Tractor drawn disc plough followed by two cross harrowing and planking. The field was thoroughly leveled by a leveler before it was laid out. Manure and fertilizer were applied according to recommended doses foronion i.e. 25-30 t/ha. FYM or compost along with fertilizer N: P: K @ 80-125: 50-75:80-125 kg per ha ${ }^{-1}$. FYM was well incorporated in plots at least 20 days before transplanting. Apply 50\% nitrogen and entire dose of $\mathrm{P}_{2} \mathrm{O}_{5}$ and $\mathrm{K}_{2}$ Obefore transplanting or set sowing and remaining half nitrogen is top dressed 5-6 week after transplanting. Seven week old seedlings were transplanted in the experimental plots after allotting entries randomly in each replication. Before transplanting, healthy and uniform seedlings 
were selected and the selected seedlings were dip the roots in the solution of Bavistin @ $2 \mathrm{~g} /$ liter to save the crop from pink rot diseases. On the day of transplanting, the field was irrigated and seedlings were transplanted. Gap filling was done seven days after transplanting. Hand weeding was done five times at 20, 40, 65, 90 and DAT.

\section{Results and Discussion}

The results obtained from the present investigation are summarized below:

\section{Growth attributes of onion}

Plant height, leaf length and number of leaves were significantly increased with increasing level of nitrogen $120 \mathrm{~kg} \mathrm{ha}^{-1}$. The contribution of Azospirillum inoculation in increasing the growth characters such as plant height, leaf length and number of leaves was significant as compared to no inoculation (control).

The maximum growth in term of plant height $49.10 \mathrm{~cm}$ was obtained with application of $120 \mathrm{~kg} \mathrm{ha}{ }^{-1}$ nitrogen along with $\left(\begin{array}{lll}\mathrm{B}_{1} & \mathrm{~N}_{3}\end{array}\right)$ Azospirillum inoculation. Followed by $\mathrm{B}_{1} \mathrm{~N}_{2}$ $(48.90 \mathrm{~cm}) 120 \mathrm{~kg} \mathrm{ha}^{-1}$ nitrogen along with Azospirillum inoculation. However minimum plant height was recorded $\mathrm{B}_{0} \mathrm{~N}_{0}$ in control $(48.22 \mathrm{~cm})$.

The maximum leaf length $44.93 \mathrm{~cm}$ was obtained with application of $120 \mathrm{~kg} \mathrm{ha}^{-1}$ nitrogen along with $\left(\begin{array}{lll}\mathrm{B}_{1} & \mathrm{~N}_{3}\end{array}\right)$ Azospirillum inoculation.

Followed by $\mathrm{B}_{1} \mathrm{~N}_{2}(44.76 \mathrm{~cm}) 120 \mathrm{~kg} \mathrm{ha}^{-1}$ nitrogen along with Azospirillum inoculation. However minimum leaf length was recorded in $\mathrm{B}_{0} \mathrm{~N}_{0}$ control $(44.09 \mathrm{~cm})$.

The maximum number of leaves per plant 9.32, was was obtained with application of $120 \mathrm{~kg} \mathrm{ha}{ }^{-1}$ nitrogen along with $\left(\begin{array}{lll}\mathrm{B}_{1} & \mathrm{~N}_{3}\end{array}\right)$
Azospirillum inoculation. Followed by $\mathrm{B}_{1} \mathrm{~N}_{2}$ (9.11) $120 \mathrm{~kg} \mathrm{ha}^{-1}$ nitrogen along with Azospirillum inoculation. While minimum number of leaves per plant was under $\mathrm{B}_{0} \mathrm{~N}_{0}$ control (8.37).

This finding has been supported by several workers Kumar and Kumar (2001), (Neeraja et al., 2001) Singh et al., (2004), Nasreen et al., (2007), Farooqui et al., (2009) and Dudhat et al., (2010) have reported similar findings by applying different doses of nitrogen in different climatic conditions of onion cultivation.

\section{Yield attributes of onion}

The contribution of Azospirillum inoculation in increasing the yield characters such as diameter of bulb, weight of bulb and yield was significant as compared to no inoculation (control). The attributing character viz. bulb diameter and weight of bulb was found to be significant by application of maximum dose of nitrogen along with Azospirillum inoculation.

The maximum bulb yield (279.22 $\mathrm{q} \mathrm{ha}^{-1}$ ) was found by applying $120 \mathrm{~kg} \mathrm{ha}^{-1}$ along with $\left(\mathrm{B}_{1} \mathrm{~N}_{3}\right)$ Azospirillum. However, the minimum bulb yield was recorded $\left(252.22 \mathrm{q} \mathrm{h}^{-1}\right)$ with rest doses of nitrogen and Azospirillum. Application of nitrogen significantly enhanced the bulb diameter and weight of bulb. The maximum value for this character was obtained at $120 \mathrm{~kg} \mathrm{ha}^{-1}$. The total bulb yield significantly increased and the maximum yield $270.55 \mathrm{q} \mathrm{ha}^{-1}$ as compared to rest doses of nitrogen (Table 1 ).

The interaction of Azospirllum and nitrogen level significantly increased yield attributes except diameter of bulb (cm) and bulb weight in (g). Similarly, finding had also been reported by Sanjay et al., (2011) and Hussain et al., (2000). 
Table.1 Effect of Nitrogen and Azospirillum inoculation on growth and yield of onion

\begin{tabular}{|c|c|c|c|c|c|c|c|}
\hline Treatments & $\begin{array}{l}\text { Plant height } \\
\quad(\mathrm{cm})\end{array}$ & $\begin{array}{l}\text { Leaf length } \\
\quad(\mathrm{cm})\end{array}$ & $\begin{array}{c}\text { Number of } \\
\text { leaf }\end{array}$ & $\begin{array}{c}\text { Diameter of } \\
\text { bulb (cm) }\end{array}$ & $\begin{array}{l}\text { Weight of } \\
\text { bulb (g) }\end{array}$ & $\begin{array}{c}\text { Bulb yield } \\
\text { /plot (kg) }\end{array}$ & $\begin{array}{c}\text { Bulb yield } \\
\text { ha }^{-1}(\mathbf{Q t} .)\end{array}$ \\
\hline $\mathbf{B}_{0} \mathbf{N}_{0}$ & 48.22 & 44.09 & 8.37 & 4.35 & 36.54 & 7.57 & 252.44 \\
\hline $\mathbf{B}_{1} \mathbf{N}_{0}$ & 48.49 & 44.18 & 8.56 & 4.34 & 36.53 & 7.56 & 252.22 \\
\hline $\mathbf{B}_{1} \mathbf{N}_{1}$ & 48.74 & 44.43 & 8.84 & 4.56 & 36.85 & 7.69 & 256.33 \\
\hline $\mathrm{B}_{0} \mathrm{~N}_{2}$ & 48.69 & 44.40 & 8.80 & 4.55 & 36.87 & 7.64 & 254.77 \\
\hline $\mathbf{B}_{1} \mathbf{N}_{3}$ & 49.10 & 44.93 & 9.32 & 4.75 & 38.10 & 8.37 & 279.22 \\
\hline S.E.+ & 03.950 & 01.489 & 01.077 & 02.138 & 01.014 & 0.021 & 0.267 \\
\hline C.D. at $5 \%$ & 07.746 & 1.148 & 2.859 & 2.384 & 1.185 & 0.052 & 1.457 \\
\hline
\end{tabular}


On the basis of overall findings of the present research study it was concluded that the application of nitrogen along with Azospirillum increased the growth and yield of onion.

The maximum plant height $49.10 \mathrm{~cm}$, leaf length $44.93 \mathrm{~cm}$, number of leaves per plant 9.32 , diameter of bulb $4.75 \mathrm{~cm}$, weight of bulb $38.10 \mathrm{~g}$, bulb yield $\left(8.37 \mathrm{q} \mathrm{ha}^{-1}\right)$ was found by applying $120 \mathrm{~kg} \mathrm{ha}^{-1}$ along with $\left(\mathrm{B}_{1} \mathrm{~N}_{3}\right)$ Azospirillum.

However, the maximum yield was recorded $\left(279.22 \mathrm{q} \mathrm{h}^{-1}\right)$ with rest doses of nitrogen and Azospirillum. Hence we can recommend that the application of with Azospirillum along with $120 \mathrm{~kg} \mathrm{ha}^{-1}$ nitrogen is a promising approach to increase the growth and and yield of onion.

\section{References}

Dudhat, M. S., Chovatia, P. K., Sheta, B. T., Rank, H.D. and Parmar, H. V. 2010. Effect of nitrogen, phosphorous and potash on growth and bulb yield of onion (Allium cepa L.). Asian J. Soil Sci. 5(1): 189-191.

Farooqui, M.A.; Naruka, I.S.; Rathore, S.S.; Singh, P.P. and Shakfamat, R.P.S. 2009. Effect of nitrogen and sulphur levels on growth and yield of garlic (Allium sativum). As. J. Food Ag. Ind, Special Issue, 518-523.

Hussain, M.A. and Amans, E.B. 2000. Yield, bulb size distribution and storability of onion (Allium cepa L.) under different levels of $\mathrm{N}$ fertilization and irrigation regime. Trop. Agric. 77 (3) 145-149.

Jayathilake, P.K.S., Reddy, I.P. Srihari, D., Neeraja, G. Ravinder-Reddy, Reddy, R. 2002. Effects of nutrient management on growth yield and yield attributes of Ravi onion (Allium cepa L.). Vege. Sci. 29 (2): 184-185.

Joshi, V.R. 2005. Studies on integrated approach on improvement of marketable bulb yield and keeping quality of kharif onion (Allium cepa L.). Ph.D. Thesis submitted to Mahatma Phule Krishi Vidyapeeth, Rahuri (Maharashtra).

Kumar, D., Kumar, S., and Kumar, A. 2001. Effect OF different levels of nitrogen on growth and yield of onion (Allium cepa L.) Indian Agril. Sci. Digest 2 (21): 121123.

Nasreen, S.; Haque M.M.; Hussain. M.A. and Farid, A.T.M. 2007. Nutrient uptake and yield of onion as influenced by nitrogen and sulphur fertilizer. Bangladesh $J$. Agril. Res., 32 (3); 413-420.

Neeraja, G., Reddy, K.M. Reddy, M.S., and Rao, V.P. 2001. Influence of irrigation and nitrogen levels on bulb yield, nutrient uptake and nitrogen use efficiencies in rabi onion (Allium cepa). Indian J. Agric Sci. 71 (2): 109112.

Sanjay Kumar, Anoop Kumar and Yadav, Y. C. 2011. Efficacy of bio-fertilizers with NPK on growth and yield of onion 101 (Allium cepa L.) cv. NASIK RED. Asian J. Hort. 6(1): 256258.

Singh V. and Pandey M. 2006. Effect of integrated nutrient management on yield of and nutrient uptake by onion and on soil fertility. J. Indian Soc. Soil Sci. 54(3): 365-367.

Singh, S. Yadav, P.K. and Singh, B. 2004. Effect of nitrogen and potassium on growth and yield of onion (Allium cepa L.) cv. Pusa Red. Haryana J. Horti. Sci. 33 (3\&4): 308-309.

\section{How to cite this article:}

Anish Kumar, Balaji Vikram and Singh, P.K. 2019. Response of Nitrogen and Azospirillum Inoculation on Growth and Yield of Onion (Allium cepa L.) cv. Pusa Red. Int.J.Curr.Microbiol.App.Sci. 8(06): 1327-1331. doi: https://doi.org/10.20546/ijcmas.2019.806.160 